\title{
Business Process Design for Widuri Indah School Management System with the Support of Cloud Computing
}

Yulyanty Chandra*, Roy Willis, Calvin Windoro, Sfenrianto

Information Systems Management Department, BINUS Graduate Program-Master of Information Systems Management, Bina Nusantara University, Jakarta, Indonesia 11480

\begin{tabular}{l} 
A R T I C L E I N F O \\
\hline Article history: \\
Received: 02 May, 2020 \\
Accepted: 14 June, 2020 \\
Online: 25 June, 2020 \\
\hline Keywords: \\
Cloud computing \\
Business Process \\
School Management System \\
Information system \\
\hline
\end{tabular}

\begin{abstract}
A B S T R A C T
This study aims to design business processes or school management solutions that are right for the school. Widuri Indah School is private school that has not been integrated with the school management system. Qualitative method such as observation and interview are conducted to gain insights about main activities and support activities in Widuri Indah school business process. Furthermore, designing the use case diagram to construct the business process. The design will be able to produce business process that can integrating between users at school and school management systems in a cloud-based process It can be used as a guide in the procurement of school management system based on clout computing. The design is believed to bring improvement such as interoperability, flexibility, data management, and efficiency as a result.
\end{abstract}

\section{Introduction}

The world of Education has not yet fully raised all its problems in Indonesia. Various efforts and activities are always carried out to improve the innovation and quality of the system that carries the name of education has been carried out by the government, until now. The world of education should mean the availability of various solutions to support educational programs to create an education system that can support and enhance the activities of users at school. However, the use of IT in Indonesia has just entered the stage of studying various possibilities for the development and application of IT for education. When examined in detail in this regard, the government has sought to improve the quality of Indonesia's education, what exactly is at the core of the problem in the world of education, may be far more difficult. Schools in Indonesia are not yet connected with technology in the process, have not yet reached the mind power and adequate sources of information. The solution to all the problems above is an academic information system that is used to monitor all educational activities and is able to produce information that is needed by the school, government, students, guardians and the public at large and up to date. The system must be accessible whenever and wherever and be able to generate information automatically without the need for manual calculations that are error prone and result in incorrect information, and certainly can

\footnotetext{
*Yulyanty Chandra, Email: yuliyantychandra@binus.edu
}

support quick decision making. Widuri Indah School's system has not utilized technology as the main base for automation. All things especially administration for payment of school fees is still manually by queuing making payments in school administration. Information such as report card grades, student absences and attendance and submission of teacher and employee leave are still manual, and student assignment information has not been connected to any technological media. This study aims to produce design needs in terms of technological infrastructure in Indonesia in the form of catalogs, diagrams, and matrices that will be needed by Widuri Indah Schools in developing their school management.

\section{Literature Review}

A good education in the world should have a good business system and process, where the ultimate goal itself is not only to support teaching and learning in schools, but also that an integrated system can support the internal operational performance of schools. A well-integrated system will be able to make decisions faster than using a manual or traditional system.

\subsection{Business Process}

According to [1], in his book "Business Process Change" (2003), the definition of a business process is a series of activities carried out by a business which includes the initiation of input, transformation of information, and producing output. The output can be valuable for business or market customers, it can also be 
valuable for other processes (within the organization). A business process can be broken down into several processes, each of which has its own role to achieve its goals. Sub-processes can be broken down into activities, which are the smallest processes that can consist of one or more steps that must be included in a business process [2] [3].

Business process development is needed by an educational institution with the aim of improving internal quality management [4]. Therefore, the business processes that run on educational institutions are needed to be analyzed in accordance with the needs of management and institutions [5]. Use case is one of the approaches used to design business processes [6].

\subsection{School Management System}

School Management system is an information system used by educational institution for specific purposes. For example, the Smart School Management System (SSMS) which is used to assist learning activities and Information systems management of schools in Malaysia [7]. While Smart school management in Indonesia, one of them is edConnect as an information system that simplifies administrative work, improves information accessibility, facilitates intensive communication, and provides data visibility for all aspects of the school.

For its own definition, School Management Information System is a design that adjusts the structure, task management, learning processes and the special needs of schools by utilizing information systems management [8]. The purpose of the existence of a school management information system is to support management and educational activities by school managers by utilizing information [9]. It can be concluded that the school management information system is a structural design, task management and special needs of schools that are both direct and indirect learning processes that are used by school managers by utilizing information systems management.

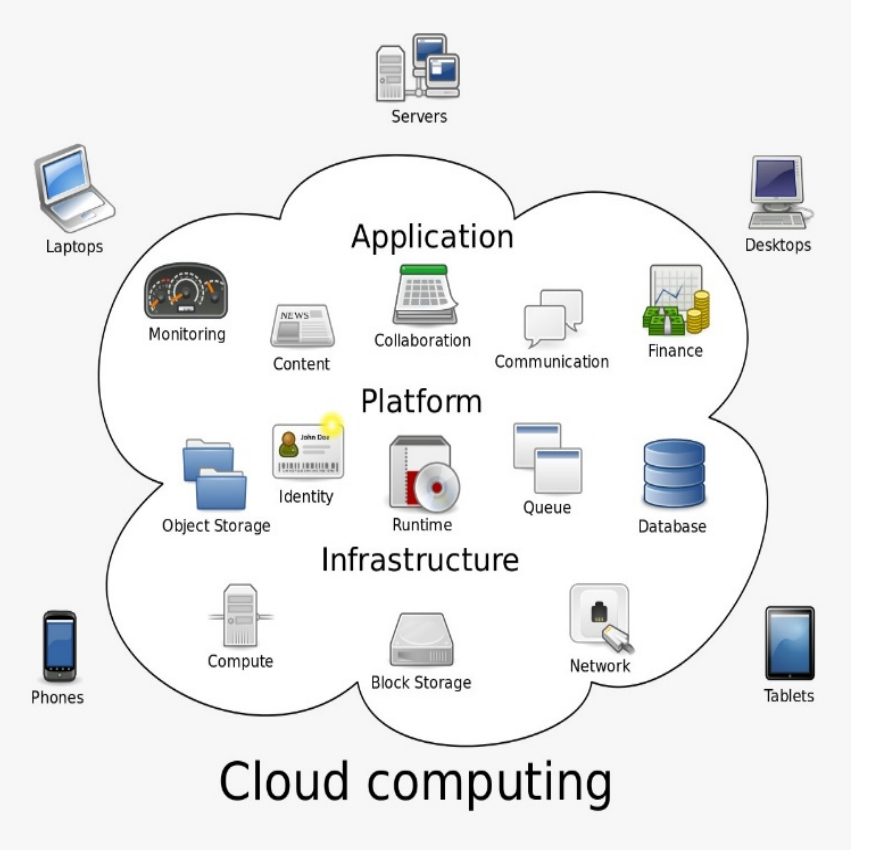

\subsection{Cloud Computing}

Figure 1 shows the three main components used to support cloud computing, namely Infrastructure, Platforms and Applications [10]. There are several infrastructures from clout computing such as server, network, storage, and digital technology that are needed.

Cloud Computing (Cloud computing) is a combination of computer technology and internet networks [11]. Cloud (Cloud) is part of the internet, as the cloud is in the picture of an organization's internet network pattern. Apart from being like a cloud in a computer network diagram, the cloud (cloud) in cloud computing is also an integrated network infrastructure [10].

The term cloud has been widely used in the development of the Internet world, because the Internet can be said to be a large cloud. Cloud computing itself is a computing model, where its resources such as processor / computing power, storage, network, and software become abstract and are provided as services on the network / internet using remote access patterns.

There are many issues that can be solved by cloud. For instance, If the company not sure where to store information, a cloud server is a perfect way to reduce confusion. Cloud infrastructure has evolved tremendously and is now safer and more robust than conventional on-site technologies. Therefore, cloud can also be the answer in solving security issues. Cloud computing decreases or removes the requirement for businesses to buy hardware and develop and run data centers, hence will lead to cost efficiency.

Analytics, AI, and the prospect of safe communication beyond the corporate area give an incentive to implement a cloud infrastructure. Also, one of the benefits of cloud infrastructure for companies is how convenient it is for team leaders to operate from anywhere. Businesses have traditionally been connected to wherever their hardware is based, as that is where they need to get access to all their records. The cloud, though, allows users to carry their data with them everywhere they go.

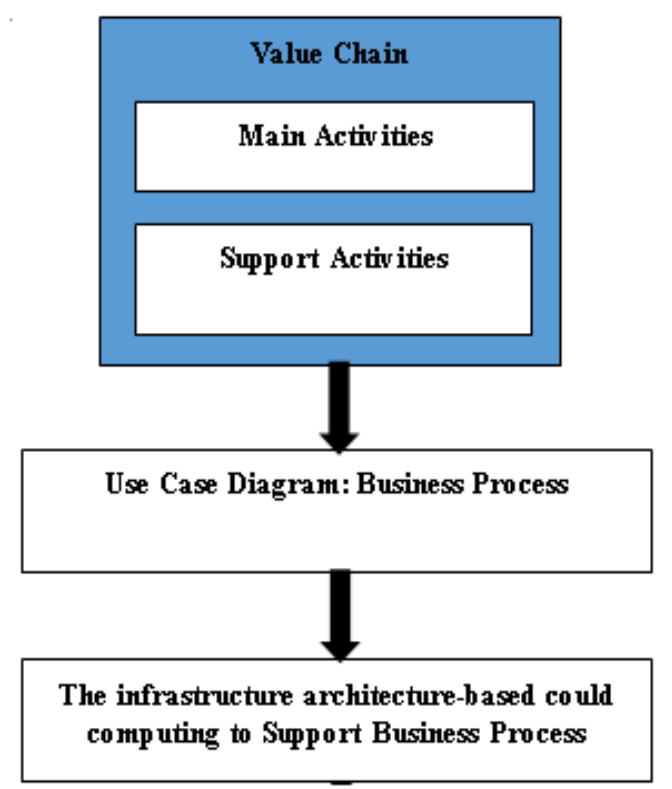

Figure 1: Cloud Computing

Figure 2: Research Design Stages 


\section{Methodology}

The method used is a qualitative method that is observation and interview. Figure 2 shows research design stages. The design begins by explaining the main activity and supporting processes that exist in the management of the Widuri Indah school's business process. Modeling that will be used is value chain which is a tool to describe main activities and support activities.

Then defining the parts of the business process, determine the relationship of information systems with business processes from Widuri Indah School's management, and detailed the specific business process by using use case diagram to make a clear related part to the system. The final design is making the infrastructure architecture-based cloud computing for the steps internal structure for the school.

\section{Result and Discussion}

This section presents the result of study for design business process bases on cloud computing to support Widuri Indah School Management System. The following value chain explains the process of main activities and supporting activities (see Figure 3).

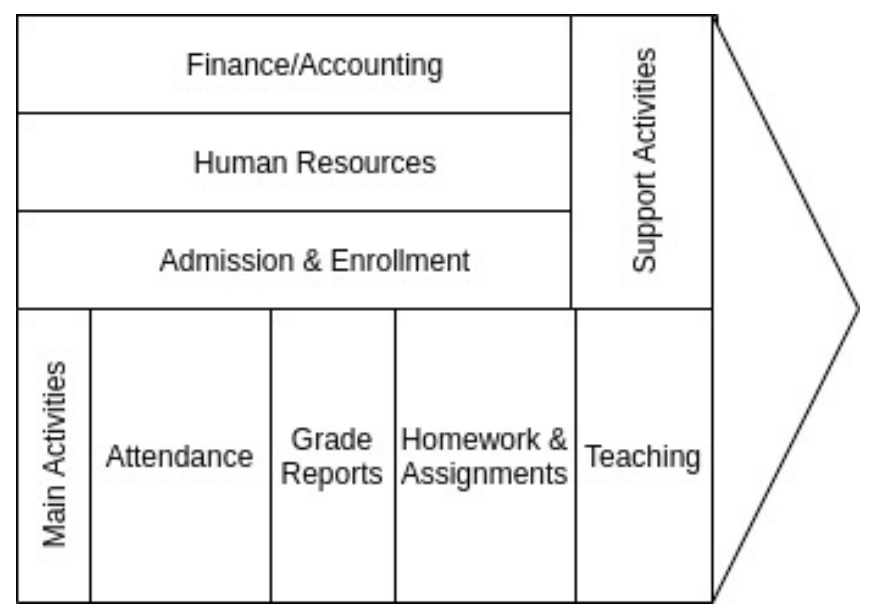

Figure 3: The Value Chain of main activities and support activities

Based on figure 3, the main activities are attendance, grade reports, homework and assignments, and Teaching. The Attendance is a data collection of the presence of students every morning at school and attendance data of teachers, and employees at the school. Grade reports are the grades given from the teacher to the students in the form such as; PH (Daily assessment), PTS (Middle semester assessment), PAS (End of semester assessment) and PAT (End of year assessment).

Then, homework and assignments are given to students every day to provide exercises to keep in mind the lessons given on that day, and train students to be able to think independently in doing assignments. The final main activity is Teaching, that provided by the teachers every day at school, providing daily teaching material for students, where the material taught is in accordance with the curriculum applied at school.

While for the supporting activities are finance and accounting, human resources, and admission \& enrollment. For finance and accounting, work to record the financial statements of students, especially for reports income from school fees every month, uniform and book sales reports, and annual school budget data collection for various needs such as school operational costs, budget for providing school equipment, and others.

Then, human resource is recording the recap of teacher attendance data, along with the application for leave or permit and record the data of teachers in schools that relate to official data in Dapodikdasmen. While admission \& enrollment is tasked to accept the registration of new students at the school along with all the completeness documents that must be fulfilled by parents of prospective students.

The next design is to define the business process parts which are the details of each business process that can be seen in the use case diagram below (see Figure 4).

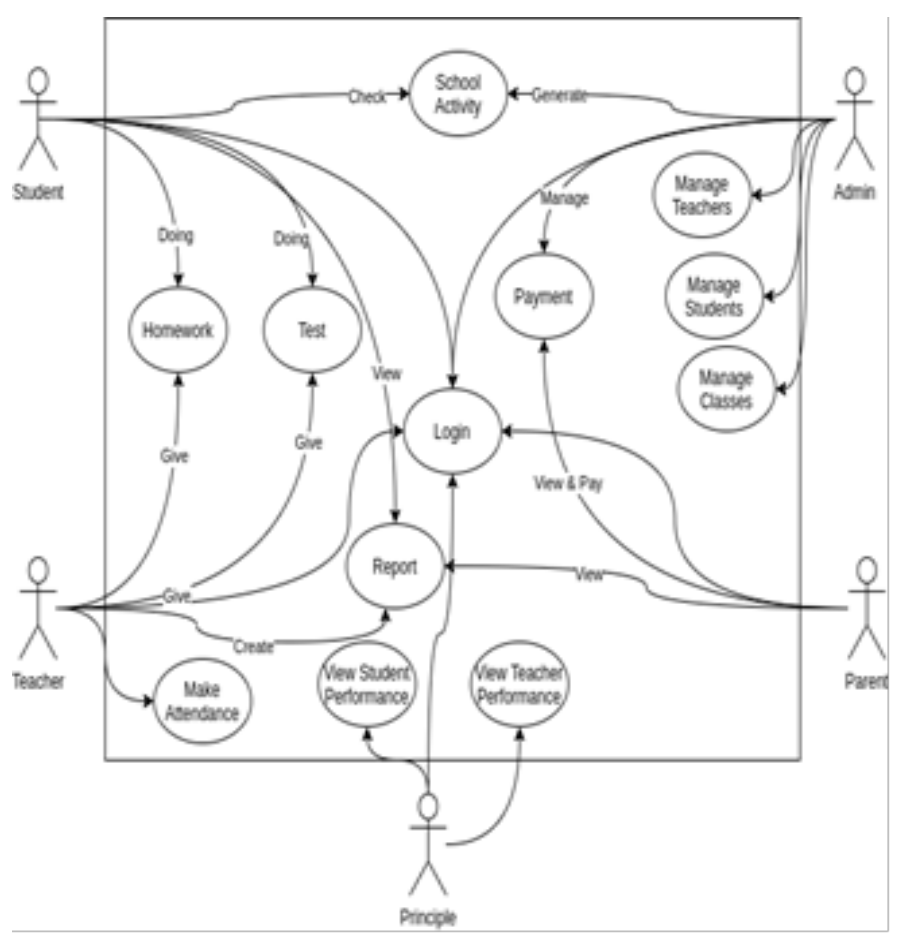

Figure 4: Use Case Diagram business process

From the Use Case Diagram above consist of five actors, they are student, teacher, parent, principle, and admin. They all have the access to the school system management. This use case diagram covers all main activities and support activities in Figure 3.

The principle only has the access to look after student and teacher overall performance as information. To maintain students' grades and keep the teacher on track and achieving their key performance indicator is the main principle's work to be done.

The admin has the access to manage teachers, students, and classes scheduling. Schedule management is crucial to ensure the student and the teachers neatly and precisely assigned to the same class with the subject. The admin also manages the any fees might needed for school operational such as monthly school fees, administration fees, etc. Any kind school activities will be updated by the admin and can directly inspected by the student.

The students and the teachers have interrelation process. The teachers will give assignments and the test to the students. The students will also complete their assignments or test's answer in reply. The teacher generates the report which can be viewed by the students. The teacher specifically has the authority of 
attendance checking.

The parents usually only accomplish their duty in terms of payment and checking the report created by the teacher according to students' learning outcomes, especially homework and examination results.

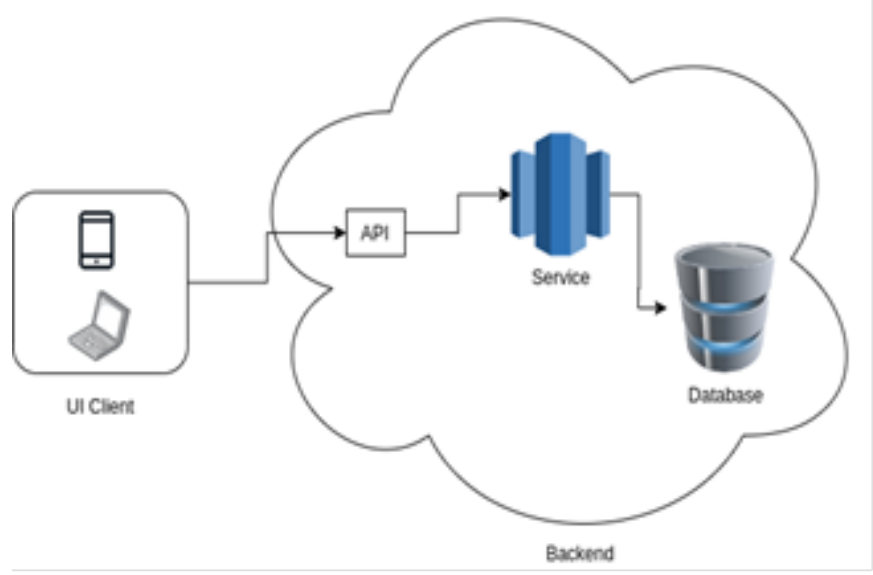

Figure 5: Infrastructure Architecture-Based Cloud Computing

Figure 5 shows a cloud-based architecture. Cloud architecture was chosen over architecture on premise because schools are public places, and it is feared that there will be physical damage or loss. With cloud-based architecture, it can scale their computing solutions as they need. When on the holiday, the student very rare to open the school management system, so the school can decrease the computing resources to make it more efficient. This solution also enables a flexible workplace. Because all information is stored in the cloud, the student and teacher can continue their activity from anywhere, especially when they cannot come to school. With all this advantage, cloud-based architecture can increase productivity.

\section{Conclusion}

Based on the results of the design that has been done and explained, it can be concluded that by using business processes and cloud technology, teaching and learning processes and other supporting processes can run more optimally. Improvements can be seen in interoperability, flexibility, data management, and efficiency. Apart from that, using cloud was chosen compared to on premise because of physical security reasons from cloud architecture far better than architecture on premise.

\section{References}

[1] Harmon, P. (2003). Business process change: a manager's guide to improving, redesigning, and automating processes. Morgan Kaufmann. ISBN-13: 978-1558607583, ISBN-10: 1558607587

[2] Harmon, P., \& Trends, B. P. (2010). Business process change: A guide for business managers and BPM and Six Sigma professionals. Elsevier. Paperback ISBN: 9780123741523 , eBook ISBN: 9780080553672

[3] Nurhayati, L., \& Setiadi, D. (2017). Pemodelan Proses Bisnis (Studi Kasus PD. Simpati Sumedang). Infoman's: Jurnal Ilmu-ilmu Manajemen dan Informatika, 11(1), 40-50. DOI: 10.33481/infomans.v11i1.39

[4] Sapunar, D., Grković, I., Lukšić, D., \& Marušić, M. (2016). The business process management software for successful quality management and organization: a case study from the University of Split School of Medicine. Acta medica academica, 45(1), 26, DOI: 10.5644/ama2006-124.153

[5] Putra, D. M. D. U., \& Welda, W. (2019). Business Process Analysis and Modeling Using the Business Process Improvement Framework at the
Internal Quality Assurance STMIK STIKOM Indonesia. ACSIE (International Journal of Application Computer Science and Informatic Engineering), 1(2), 75-86. DOI https://doi.org/10.33173/acsie.53

[6] Röglinger, M., Seyfried, J., Stelzl, S., \& zur Muehlen, M. (2017, September). Cognitive computing: what's in for business process management? An exploration of use case ideas. In International Conference on Business Process Management (pp. 419-428). Springer, Cham. DOI: 10.1007/978-3319-74030-0 32

[7] Hussein, S. M., Shariff, S. A., \& Mantoro, T. (2017). Parental Involvement and Awareness Using Malaysian's Smart School Management System. Advanced Science Letters, 23(2), 712-716. ISSN 1936-6612

[8] Moshe, T. (1999). A case study of the impact of school administration computerization on the department head's role. Journal of Research on

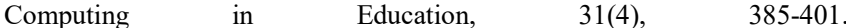
https://doi.org/10.1177/0042085998033004004

[9] Demir, K. (2006). School Management Information Systems in Primary Schools. Online Submission, 5(2). ISSN: 1303-6521 volume 5 Issue 2 Article 6

[10] Pyar, K., \& Khaing, M. M. (2019). Clout Computing Basic : Feature and Service., International Journal of Trend in Scientific Research and Development (IJTSRD), Vol. 3 Issuu 5, ISSN: 2456-6470, Volume-4 | Issue3, April 2020

[11] Waloeyo, Y. J. (2012). Cloud computing-Aplikasi Berbasis Web yang Mengubah Cara Kerja dan Kolaborasi Anda Secara Online. Andi Offset, Yogyakarta. ISSN: 978-979-29-2302-5 